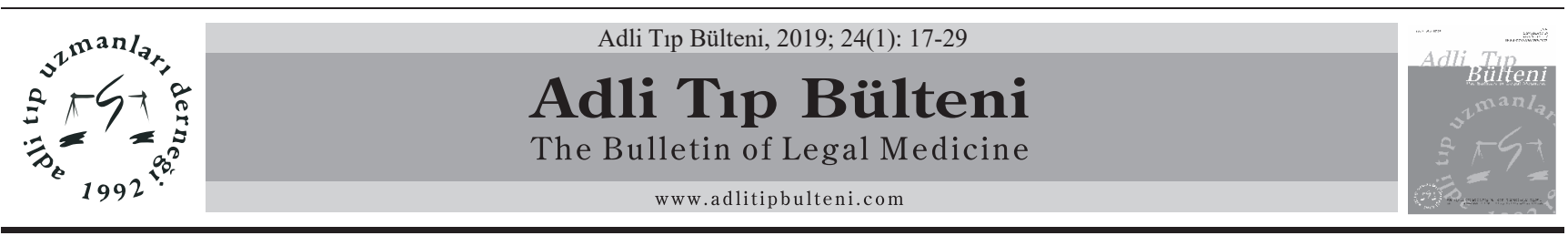

\title{
ARAŞTIRMA / RESEARCH ARTICLE İnsan İskeletlerinde Travma: Travmaya Bağlı Ölüm Nedeni Üzerine Bir Araştırma
}

\section{Trauma on Human Skeletons: A Study on Cause of Death Related with Trauma}

\author{
Deren Çeker*, İdris Deniz, Ayla Sevim Erol
}

\begin{abstract}
$\ddot{O ̈}_{z}$
Amaç: Adli Antropoloji'de, insan kemiklerindeki kırıklar, ezikler, kesikler ve delikler analiz edilerek travma çeşidi, ölüm şekli ve buna bağlı muhtemel ölüm nedeni tahminleri yapılmaktadır. Bu çalışmanın amacı, ölüm nedeni travmaya bağlı bireylerin kemiklerindeki kırıkları, BT kullanarak perimortem süreçte incelemek, kırıkların ölümle ilişkisini belirlemek ve adli antropolojik raporlardaki perimortem travma tanımlamalarının güvenilirliğini test etmektir.

Gereç ve Yöntem: Bu çalışmanın materyali, 20.02.2016-29.11.2017 tarihleri arasında travmaya bağlı ölen 23'ü erkek ve 7'si kadın, 30 adli vakadan oluşmaktadır. Vakalar, trafik kazaları, yüksekten düşme, ip ile ası eylemi ve ateşli silah yaralanması olayları ile temsil edilmektedir. Bireylerin BT verileri, bir vaka hariç, ağır yaralı olarak getirildikleri hastanede ölüm öncesinde çekilmiş, üç boyutlu medika görüntüleme programı kullanılarak vücutlarındaki kırıklar tespit edilmiştir.

Bulgular: 30 bireye ait 1580 adet kemik incelenmiş ve 242'nde travma tespit edilmiştir. Travma çeşitleri ve muhtemel ölüm nedenleri, adli otopsi sonuçlarından habersiz belirlenerek, daha sonra adli otopsi sonuçları ile karşılaştırılmıştır. Bulgular, 28 kişinin künt travmaya bağlı ve 2 kişinin ateşli silah yaralanması nedeniyle hayatlarını kaybettiğini göstermiştir. Erkek bireylerin ölüm oranının kadınlara göre daha fazla olduğu, travmaya bağlı ölümlerin en çok 21-30 yaş aralığında gerçekleştiği ve ölüme sebebiyet veren kırıkların en fazla kafatası ve göğ̈̈s bölgelerinde meydana geldiği gözlemlenmiștir.

Sonuç: Bu çalışmadaki adli antropolojik analizlerin, travma çeşidi tespitinde \%90 (n=30/27), ölüm nedeni tahminlerinde $\% 86.6(n=30 / 26)$ oranında başarı yüzdeliğine sahip olduğu görülmüştür. Ayrıca, travma çeşitlerine göre kırılma özellikleri ayrıntılı olarak tanımlanmıştır. Bu tanımlamalardan hem adl antropoloji, hem de antik dönem iskelet çalışmalarında yararlanılabilecektir. Sonuç olarak bu çalışma adli antropoloji ve biyolojik antropoloji çalışmalarında travma analizlerinde kullanılabilecek bir referans çalışma niteliği göstermektedir.
\end{abstract}

Anahtar Kelimeler: Adli Bilimler; Adli Antropoloji; İskelet; Perimortem; Travma; Ölüm Nedeni.

\section{Abstract}

Objective: In forensic anthropology, skeletal trauma analysis is conducted to determine the patterns of trauma in violent deaths. Bone fractures, cut marks and other defects observed on the human bones are analyzed in order to determine the manner and the possible cause of death. The aim of this study was to examine bone fracturing patterns of the victims, utilizing CT scans so as to diagnose the relationship between bone fracture and mortality. It also tested the accuracy and reliability of the perimortem trauma determinations in the forensic anthropological results.

Materials and Methods: The sample of this study consists of 30 cases of forensic significance, and includes 23 male and 7 female individuals who died from traumatic injuries between 20.02.2016 and 29.11.2017. The victims died from traffic accidents, fall from height, hanging and firearm. Gravely in jured individuals underwent CT scanning in the national hospital prior to death except for one individual and bone fractures were located by using a 3D medical imaging program.

Results: 1580 bones were analyzed and 242 bone fractures were located, independent to the autopsy findings. The results of the study indicated that 28 individuals died from blunt trauma and 2 individuals from gunshot trauma, the number of deaths for men was greater than for females, the highest mortality age range was between 21 and 30 years old and fatal bone fractures were mostly located on the head and chest.

Conclusion: Forensic anthropological analysis results were found to have a success rate of $90 \%$ $(n=30 / 27)$ in determining the trauma type and $86.6 \%$ in determining the cause of death $(n=30 / 26)$ with the autopsy results. In addition, fracture characteristics are also defined in detail according to trauma types. These detailed trauma descriptions can also be used in both forensic anthropology and bioarchaeology. This study can be used as a reference for trauma analysis both in forensic anthropology and biological anthropology studies.

Keywords: Forensic Sciences; Forensic Anthropology; Skeleton; Perimortem; Trauma; Cause of Death

\section{DOI: $10.17986 / \mathrm{blm} .2019149812$}

Deren Çeker: PhD, KKTC Dr. Burhan

Nalbantoğlu Devlet Hastanesi, Adli Tıp

Birimi, Lefkoşa

Eposta: derenceker@hotmail.com ORCID iD: https://orcid.org/00000002-0262-260X

İdris Deniz: Uzm. Dr., KKTC Dr. Burhan Nalbantoğlu Devlet Hastanesi, Adli Tıp Birimi, Lefkoşa Eposta: idrsdnz@gmail.com ORCID iD: https://orcid.org/00000002-7986-4658

Ayla Sevim Erol: Prof. Dr., Ankara Üniversitesi, Dil ve Tarih-Coğrafya Fakültesi, Antropoloji Bölümü, Ankara Eposta: ayla_sevim@hotmail.com ORCID iD: https://orcid.org/00000001-7776-3864

\section{Bildirimler:}

Yazarlar bu makale ile ilgili herhangi bir çıkar çatışması bildirmemişlerdir.

Geliș: 29.10.2018

Düzeltme: 07.12.2018

Kabul: 13.12.2018

p-ISSN: $1300-865 \mathrm{X}$

e-ISSN: 2149-4533 


\section{Giriş}

Adli vakalarda, kemiklerdeki kırıklara bağlı ölümler kasitlı veya kasitsız olaylar neticesinde meydana gelirler. Travmaların kemiklerde oluşturduğu kırık özelliklerinin uzmanlar tarafindan incelenmesi ve neticesinde ölüm sebeplerinin belirlenmesi sadece hukuki bir gereklilik değil, insani ve toplumsal değerler açısından da önemlidir (1-4). Hukuki prosedürlerin yerine getirilebilmesi için kişilerin nasıl öldüğünün veya öldürüldüğünün ortaya çıkarılmasına ihtiyaç vardır. Buna bağlı olarak, adli tıp uzmanları yaptıkları iç ve dış muayenelerle ölüm sebebini ortaya çıkarmakta, bunu yaparken de adli kimya, toksikoloji, mikrobiyoloji, patoloji ve genetik bilimlerinden yararlanmaktadırlar.

Adli vakalarda cesetler her zaman iyi korunmuş durumda bulunmazlar. Öldükten uzun zaman sonra ve/veya çevresel faktörlere bağlı olarak cesetler, yumuşak doku ve iç organları çürümüş, yanmış, mumyalaşmış, sabunlaşmış, iskeletleşmeye yüz tutmuş veya tamamen iskeletleşmiş durumda bulunabilmektedir. Bu tür vakalarda adli antropoloji bilimi metot ve teknikleri kullanılarak teşhis edilemez ve otopsi yapılamaz hale gelmiş cesetlerin biyolojik profilleri (yaş, boy, cinsiyet, etnik köken), dental özellikleri, yaşa veya hastalığa bağl1 kemiklerde gözlemlenen patolojik durumları, ölüm sonrasına ait tafonomik sebeplerden meydana gelmiş değişikliklerle birlikte, ölüm zamanına ait travmalar incelenerek muhtemel ölüm nedenleri belirlenebilmektedir (5-13). İnsan iskeletlerinde ölüm zamanına ait travmalar, kemiklerde tespit edilen kırık, çizik/kesik, yarık, delik, çökme ve deformasyonların analizleri ile mümkün olabilmektedir. Böyle vakalarda görev alan adli antropologların travma bulguların doğru tanımlaması ve muhtemel ölüm sebebi hakkında bilimsel ve güvenilir sonuçlar sunması beklenir. Yanlış bir travma tanımı, yanlış bir ölüm şekli tanımlamasına sebep olabilir, kriminal ve hukuki yetkililer bu bulgulara bakarak masum bir kişiyi ölümden sorumlu tutabilir, cinayet olan bir vakayı intihar olarak değerlendirebilir veya bir cinayeti kaza olarak değerlendirip failin serbest kalmasına sebep olabilirler. Bundan dolayıdır ki, iskeletlerden travma belirleme ve tanımlama çalışmaları nitelikli, hassas ve detaylı bir çalışma gerektirdiği kadar neticeleri de, olaya dahil veya olaydan sorumlu kişiler için ve maktülün ailesinin geleceği açısından hayati önem taşımaktadır.

Burada sunulan çalışmanın başlıca amacı bireysel demografiler (yaş, cinsiyet, patolojik durumlar) ve kırıkların vücutta bulundukları lokasyonlar göz önünde bulundurularak, ölüme sebebiyet veren kemik kırıklarının, ölüm zamanındaki (perimortem) özelliklerini üç boyutlu dijital ortamda tespit ederek incelemek, travma çeşitlerinin k1rılma özelliklerini tanımlamak, muhtemel ölüm nedeni- ni tahmin etmek ve adli otopsi sonuçlarındaki travmaya bağlı ölüm nedenleri ile karşılaştırarak, adli antropolojik analizlerde ölüm nedeni belirlemede sıkça kullanılan 'muhtemel ölüm sebebi' cümlesindeki muhtemel kelimesinin güvenilirliğini test etmektir. Bunu yaparak, insan iskeletlerindeki verilerden faydalanarak ölüm nedeni ve travma mekanizması belirleme çalışmalarındaki doğruluk ve güvenilirlik oranını yükseltmek amaçlanmaktadır. Bu çalışmanın başka bir amacı da, adli antropoloji ve adli tıpta kullanılan teknik ve metotları bir araya getirerek, bu bilim dallarından doğacak yeni ve multidisipliner bir çalışma örneği sergilemek, kompleks adli vakalarda adli antropologların da adli tıp uzmanları ile birlikte çalışmalarının, adli vakaların çözümlenmesi açısından katkısına dikkat çekmek, antropoloji bilimi ve adli bilimler arasında bir köprü kurmaktır.

\section{Gereç ve Yöntem}

Bu çalışmanın materyalini, 20 Şubat 2016 ve 29 Kasım 2017 tarihleri arasında, trafik kazası, ateşli silah yaralanması, yüksekten düşme ve ip ile ası eylemi gibi olayların sonucunda, Kuzey Kıbrıs Türk Cumhuriyeti Lefkoşa ilçesinde bulunan Dr. Burhan Nalbantoğlu Devlet Hastanesi acil servisine ağır yaralı olarak getirilmiş, bilgisayar11 tomografisi çekildikten kısa bir süre sonra hayatlarını kaybetmiş, otopsisi yapılmış, 14-87 yaş arası 7 kadın ve 23 erkek bireyi içeren 30 vaka oluşturmaktadır.

Bireyler, ağır yaralı olarak getirildikleri hastanenin radyoloji bölümündeki Siemens Somatom Emotions 16, bilgisayarlı tomografi (BT) ile taranmış, kırıkların perimortem BT görüntüleri çekilmiş ve RadiAnt DICOM Viewer 3.2.2 programı kullanılarak iskeletleri üç boyutlu dijital ortamda incelenmiştir. Adli antropolojik analizler esnasında kırıklar önce beş bölgeye (Kafa, Göğüs, Omurga, Batın-Pelvis, Etraf Bölgesi) ve daha sonra kendi içlerinde alt bölgelere ayrılarak (Kafatası Kemikleri, Kaburgalar, Omuz Kemikleri (Skapula-Klavikula-Humerus başı bölgesi), Boyun Omurları (C1-C7), Gögüs Omurları (T1-T12), Bel-karın Omurları (L1-L5), Pelvis, Kol-El Kemikleri ve Bacak-Ayak kemikleri) tek tek tespit edilmiş, görüntülenerek raporlanmıştır. Tespit edilen kemik kırıklar çeşitlerine göre ayrılmış, özellikleri tanımlanmış, yukarıda belirtilen vücut bölgelerine ve kemiklere göre dağılımı belirlenmiş, bulguların istatistik analizleri SPSS 20.0 yazılımı kullanılarak Pearson testine tabi tutulmuştur. Person testini kullanmaktaki amaç travmaya bağlı ölümlerde görülen kırık özellikleri değişkenlerinin vakalar arasındaki korelasyon ilişki düzeyini belirlemek ve bunların ölümle ilişkisini anlamaya çalışmaktır. Bu çalışmadaki korelasyon tablolarında 0.70 ve üstü rakamlar dikkate alınmıştır. Pearson testlerinde korelasyon katsa- 
yısının 0.05 'e eşit ve/veya küçük olması, o çalışmanın istatistiksel olarak anlamlı olduğunu göstermektedir. Korelasyon katsayısı 0.05 'in altına indikçe istatistiksel çalışmanın geçerliliği yükselmektedir. Bu çalışmadaki uyumlu korelasyon analizleri katsayıs1, 0.01 ve 0.05 olarak gözlemlenmiştir. Bu sonuç, yapılan mukayeselerin istatistiksel anlamda yüksek derecede geçerli olduğunu gösterir niteliktedir. Tespit edilen kırıkların, bireylerin hayati fonksiyonlarına etkisini belirlemek amacıyla, T.C Adalet Bakanlığı Adli Tıp Kurumu tarafından 2013'de yayınlanan 'Türk Ceza Kanunu'nda Tanımlanan Yaralama Suçlarının Adli Tıp Açısından Değerlendirilmesi' rehberinde belirtilen, TCK'nın 87. maddesinin 3. fikrasında yer alan 'Vücutta Kemik Kırılmasının Değerlendirilmesi: Kırığın Hayat Fonksiyonlarını Etkileme Derecesi' puanlaması kullanılmıştır $(1,2)$. Adli antropolojik incelemeler sonucundaki bulgular, Dr. Burhan Nalbantoğlu Devlet Hastanesi'nde yapılan otopsi bulgularındaki tanımlamalarla karşılaştırılmış ve insan iskeletlerindeki travmaların muhtemel ölüm nedeni belirlemede kullanılıp kullanılamayacağ 1 test edilmiştir. Tüm analizler sırasında, bulgular karşılaştırılıncaya kadar, fizik antropolog ve adli tıp uzmanı birbirinden bağımsız olarak çalışmıştır.

\section{Bulgular}

Olguların yaş, cinsiyet ve travma bulgusuna göre dağılımı Tablo 1'de sunulmuştur. Buna göre, 30 olgunun 7'si kadın ve 23'ü erkek bireylerden oluşmaktadır. En genç birey 14 (Erkek) ve en yaşlı birey 87 (Erkek) yaşındadır. Ölüm olgularının en çok görüldüğg̈ yaş aralığ 21-30 yaş olarak belirlenmiştir. Analizler,28 kişinin künt travmaya bağlı (\%93.3) ve 2 kişinin (\%6.7) ateşli silah yaralanması nedeniyle hayatlarını kaybettiklerini ortaya koymuştur. Künt travma olgularının 8'i araba kazası ( $\mathrm{n}=28, \% 28.6), 5$ 'i motosiklet kazası ( $\mathrm{n}=28, \% 17.9), 1^{\prime} \mathrm{i}$ bisiklet kazası ( $\mathrm{n}=28, \% 3.6)$, 4'ü yaya iken vasıta çarpması $(\mathrm{n}=28, \% 14.3)$, 9'u yüksekten düşme ( $\mathrm{n}=28, \% 32.1)$ ve 1 'i ip ile as eylemi $(n=28, \% 3.6)$ olayları ile temsil edilmektedir. İp ile ası vakasında, BT'de tespit edilen servikal kırıklar, künt travma çeşidi içerisinde değerlendirilmiştir.

Adli antropolojik incelemelerde kırıklar kafa, göğüs, omurga, batın-pelvis ve etraf bölgesi olarak beş bölgede incelenmiştir. $\mathrm{Bu}$ çalışmanın materyalini oluşturan bireylerde görülen kırıkların en çok kafa $(n=16)$ ve göğüs bölgelerinde ( $n=16)$, ve omurga bölgelerinde $(n=14)$ tespit edildiği görülmüştür (Şekil 1). Beş bölgede incelenen kırıklar, daha sonra kendi içlerinde de alt gruplara ayrılarak daha detaylı bir incelenmeye tabi tutulmuştur. $\mathrm{Bu}$ gruplar, kafatası kemikleri, kaburgalar, omuz kemikleri (skapula-klavikula-humerus başı bölgesi), boyun omurla-
Tablo 1. Vakaların yaş, cinsiyet ve travma demografisi

\begin{tabular}{|c|c|c|c|c|}
\hline Vaka No & Yaş & Cinsiyet & Travma Sebebi & $\begin{array}{c}\text { Travma } \\
\text { çeşidi }\end{array}$ \\
\hline 1 & 27 & $\mathrm{E}$ & Motosiklet kazası & Künt \\
\hline 2 & 22 & $\mathrm{~K}$ & $\begin{array}{c}\text { Yaya iken araba } \\
\text { çarpması }\end{array}$ & Künt \\
\hline 3 & 38 & $\mathrm{E}$ & Yüksekten düşme & Künt \\
\hline 4 & 65 & $\mathrm{~K}$ & Araba kazası & Künt \\
\hline 5 & 73 & K & Araba kazası & Künt \\
\hline 6 & 20 & $\mathrm{E}$ & Yüksekten düşme & Künt \\
\hline 7 & 56 & $\mathrm{E}$ & Araba kazası & Künt \\
\hline 8 & 14 & $\mathrm{E}$ & $\begin{array}{c}\text { Yaya iken araba } \\
\text { çarpması }\end{array}$ & Künt \\
\hline 9 & 20 & $\mathrm{E}$ & $\begin{array}{c}\text { Yaya iken araba } \\
\text { çarpması }\end{array}$ & Künt \\
\hline 10 & 25 & $\mathrm{E}$ & Araba kazası & Künt \\
\hline 11 & 28 & $\mathrm{E}$ & Yüksekten Düşme & Künt \\
\hline 12 & 29 & $\mathrm{E}$ & Motosiklet kazası & Künt \\
\hline 13 & 49 & $\mathrm{~K}$ & Motosiklet Kazası & Künt \\
\hline 14 & 74 & $\mathrm{E}$ & Yüksekten düşme & Künt \\
\hline 15 & 49 & $\mathrm{E}$ & Yüksekten düşme & Künt \\
\hline 16 & 48 & $\mathrm{E}$ & Araba kazası & Künt \\
\hline 17 & 32 & $\mathrm{E}$ & Yüksekten düşme & Künt \\
\hline 18 & 38 & $\mathrm{E}$ & Motosikleti kazası & Künt \\
\hline 19 & 45 & $\mathrm{E}$ & Silahla vurulma & Ateşli silah \\
\hline 20 & 41 & K & Silahla vurulma & Ateşli silah \\
\hline 21 & 26 & K & Araba kazası & Künt \\
\hline 22 & 39 & $\mathrm{E}$ & Yüksekten düşme & Künt \\
\hline 23 & 38 & $\mathrm{E}$ & Yüksekten düşme & Künt \\
\hline 24 & 87 & $\mathrm{E}$ & Bisikletli Kazası & Künt \\
\hline 25 & 27 & $\mathrm{E}$ & İp ile as 1 eylemi & Künt \\
\hline 26 & 24 & $\mathrm{E}$ & Yüksekten düşme & Künt \\
\hline 27 & 52 & $\mathrm{E}$ & Motosiklet kazası & Künt \\
\hline 28 & 22 & $\mathrm{~K}$ & Araba kazası & Künt \\
\hline 29 & 86 & $\mathrm{E}$ & Araba kazası & Künt \\
\hline 30 & 60 & $\mathrm{E}$ & $\begin{array}{l}\text { Yaya iken ağır } \\
\text { vasıta çarpması }\end{array}$ & Künt \\
\hline
\end{tabular}

r1 (C1-C7), göğüs omurları (T1-T12), bel-karın omurları (L1-L5), pelvis, kol-el kemikleri ve bacak-ayak kemikleri şeklinde sınıflandırılmıştır. Bu alt gruplar içerisinde yapılan detaylı incelemeler, en çok görülen kemik kırıklarının, 16 bireyde tespit edilen kafatası kemikleri kırıkları olduğunu göstermiştir ( $\mathrm{n}=30, \% 53.3$ ) (Şekil 2). 


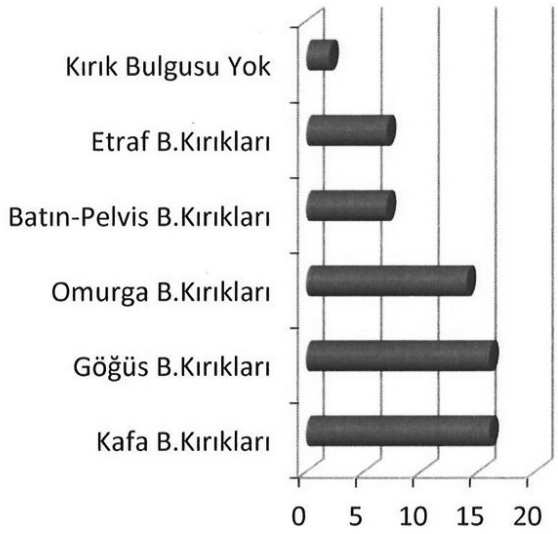

Şekil 1. Kırıkların beş vücut bölgesinde görülme dağılımı $(\mathrm{N}=$ Birey sayis1)

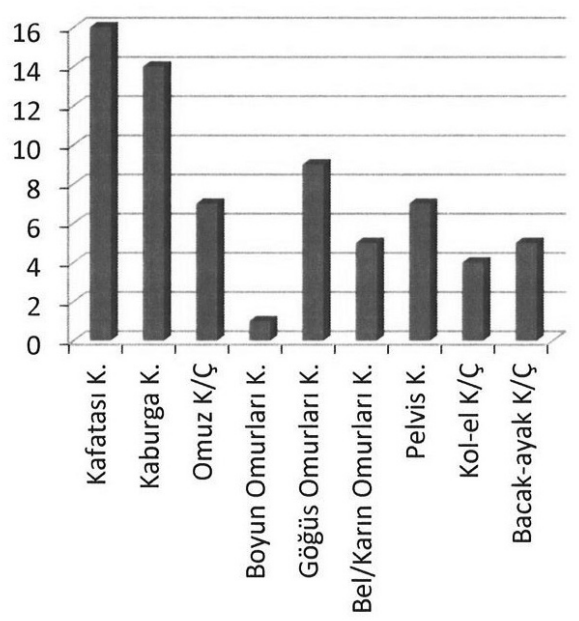

Şekil 2. En çok kırık/çıkık görülen kemikler.(N= Birey sayısı)
Bunların 2 tanesi ateşli silah travması ve 14 tanesi künt travma nedeniyle meydana geldiği görülmüştür. Kafatasında görülen kırık özellikleri değişkenlerinin tüm vakalar arasındaki korelasyon ilişkisine bakıldığında (Tablo 2), kafa bölgesi kırıkları ile kafatası kubbesi arasında çok yüksek pozitif ilişki $(\mathrm{r}(28)=.946, \mathrm{p}=0.000)$, kafa bölgesi ve kafatası kaidesi kırıkları arasında $(\mathrm{r}(28)=.897$, $\mathrm{p}=0.000$ ) yüksek pozitif ilişki, kafa bölgesi ve kafatasında çökme kırıkları arasında çok yüksek pozitif ilişki $(\mathrm{r}(28)=.904, \mathrm{p}=0.000)$, kafa bölgesi ve kafatasında ayrık kırıklar arasında çok yüksek pozitif bir ilişki $(\mathrm{r}(28)=.913$, $\mathrm{p}=0.000$ ) olduğu gözlemlenmiştir. Kafatası kubbesi kırıkları ile kafatası kaidesi kırıkları arasında yüksek pozitif ilişki $(\mathrm{r}(28)=.860, \mathrm{p}=0.000)$, kafatası kubbesi ve kafatasında çökme kırıkları arasında çok yüksek pozitif ilişki $(\mathrm{r}(28)=.903, \mathrm{p}=0.000)$, kafatasi kubbesi ve kafatasında ayrık kırıklar arasında çok yüksek $(\mathrm{r}(28)=.950, \mathrm{p}=0.000)$ pozitif bir ilişki tespit edilmiştir. Aynı şekilde kafatası kaide kırıkları ile kafatasında çökme kırıkları arasında çok yüksek pozitif bir ilişki $(\mathrm{r}(28)=.893, \mathrm{p}=0.000)$, kafatası kaide kırıkları ile kafatasında ayrık kırıklar arasında yüksek pozitif bir ilişki görülmüştür $(\mathrm{r}(28)=.869, \mathrm{p}=0.000)$. Kafatasında çökme kırıkları ile kafatasında ayrık kırıklar arasında çok yüksek pozitif bir korelasyon ilişkisi tespit edilmiştir $(\mathrm{r}(28)=.918, \mathrm{p}=0.000)$. Bu sonuçlar, 16 bireyde tespit edilen kafatası travmalarının en çok kafatası kubbesinde ve kaidesinde görüldüğünü göstermiştir. Bu kırıklar çökme ve ayrık kırıklar şeklinde veya her ikisi birlikte görülmüştür. Kafatasındaki bu kırık özellikleri değişkenlerinin yüksek pozitif ilişkiler göstermesi, kafatasındaki bu tür kırıkların birlikte görülme sıklıklarının, bireylerin ölümüne sebebiyet verme olasılıklarını artırdığını düşündürmüştür.

Tablo 2. Kafa bölgesinde görülen kırık çeşitlerinin korelasyon tablosu.

\begin{tabular}{|c|c|c|c|c|c|c|}
\hline & & KafaBk & $\begin{array}{c}\text { Kafatasikubb } \\
\text { esik }\end{array}$ & $\begin{array}{c}\text { KafatasiKaicle } \\
\text { sik }\end{array}$ & $\begin{array}{c}\text { Kafatasındac } \\
\text { okmeK }\end{array}$ & $\begin{array}{c}\text { KafatasındaAy } \\
\text { rikK } \\
\end{array}$ \\
\hline \multirow[t]{3}{*}{ KafaBK } & Pearson Correlation & 1 & 946 & 897 & .904 & .913 \\
\hline & Sig. (2-tailed) & & .000 & .000 & .000 & .000 \\
\hline & $\mathrm{N}$ & 30 & 30 & 30 & 30 & 30 \\
\hline \multirow[t]{3}{*}{ KafatasiKubbesik } & Pearson Correlation & $.946^{\circ}$ & 1 & $860^{\circ}$ & $.903^{m}$ & $950^{\prime \prime}$ \\
\hline & Sig. (2-tailed) & .000 & &, 000 & .000 & .000 \\
\hline & $N$ & 30 & 30 & 30 & 30 & 30 \\
\hline \multirow[t]{3}{*}{ KafatasiKaidesik } & Pearson Correlation & $897^{\prime \prime}$ & $860^{\circ}$ & 1 & $.893^{m}$ & $869^{\prime \prime}$ \\
\hline & Sig. (2-tailed) & .000 & .000 & & .000 & .000 \\
\hline & $N$ & 30 & 30 & 30 & 30 & 30 \\
\hline \multirow[t]{3}{*}{ KafatasındacokmeK } & Pearson Correlation & $.904^{\prime \prime}$ & $903^{\prime \prime}$ & $.893^{\circ}$ & 1 & $918^{\prime \prime}$ \\
\hline & Sig. (2-tailed) & .000 & .000 & .000 & &, 000 \\
\hline & $N$ & 30 & 30 & 30 & 30 & 30 \\
\hline \multirow[t]{3}{*}{ KafatasındaAyrikK } & Pearson Correlation & $.913^{\prime \prime}$ & $.950^{\circ}$ & $869^{\prime \prime}$ & $.918^{\prime \prime}$ & 1 \\
\hline & Sig. (2-tailed) & .000 & .000 & .000 & .000 & \\
\hline & $N$ & 30 & 30 & 30 & 30 & 30 \\
\hline
\end{tabular}

**Korelasyon 0.01 düzeyinde anlamlı (2 yönde) 
Göğüs bölgesinde tespit edilen kırıkların en çok kaburga kemiklerinde yoğunlaştığ 1 gözlemlenmiştir $(n=14$, \%47.7). Göğüs kemiklerindeki diğer kırıklar, göğüs omurlarında (T1-T12) (n=9, \%30), omuz bölgesi kemiklerinde (skapula-klavikula-humerus başı) ( $\mathrm{n}=7, \% 23.33)$ ve bel-karın bölgesi omurlarında $(n=5, \% 16.66)$ tespit edilmiştir (Şekil 2). Bu bölgelerdeki kırıkların istatistik analizleri (Tablo 4), göğüs bölgesi kırıkları ile kaburga k1rıkları arasında çok yüksek pozitif bir ilişki $(\mathrm{r}(28)=0.965$, $\mathrm{p}=0.000$ ) olduğunu ortaya koymuştur. Göğüs bölgesi kırıkları ile bel-karın bölgesi omurları kırıkları (L1-L5) arasında yüksek pozitif bir ilişki $(\mathrm{r}(28)=0.757, \mathrm{p}=0.000)$, göğüs bölgesi kırıkları ile göğüs omurları kırıkları arasında (T1-T12) yüksek pozitif bir ilişki tespit edilmiştir $(r(28)=0.721, p=0.000)$. Bu bölgeler kendi aralarında da karşılaştırılmış ve birbirleri ile uyumlulukları test edilmiştir. Buna göre, kaburga kırıkları ile gögüs omurları kırıkları arasında yüksek pozitif bir ilişki $(\mathrm{r}(28)=0.724$, $\mathrm{p}=0.000$ ), kaburga kırıkları ile bel-karın omurları arasında yüksek pozitif $(\mathrm{r}(28)=0.783, \mathrm{p}=0.000)$ pozitif bir ilişki tespit edilmiştir. (Tablo 3).

Tablo 3. Göğüs ve bel-karın bölgeleri kırıklarının korelasyon tablosu.

\begin{tabular}{|c|c|c|c|c|c|}
\hline & & GogusBK & $\begin{array}{l}\text { SittGogusBO } \\
\text { murlarikT112 }\end{array}$ & $\begin{array}{l}\text { BelKarinBOm } \\
\text { urlariKL1L5 }\end{array}$ & Kaburgak \\
\hline \multirow[t]{3}{*}{ GogusBK } & Pearson correlation & 1 &, 721 & $.757^{\prime \prime}$ &, 965 \\
\hline & Sig. (2-tailed) & & .000 & .000 & .000 \\
\hline & $\mathrm{N}$ & 30 & 30 & 30 & 30 \\
\hline \multirow{3}{*}{$\begin{array}{l}\text { SittGogusBOmurlarikT11 } \\
2\end{array}$} & Pearson Correlation & .721 & 1 & .866 & .724 \\
\hline & Sig. (2-tailed) & .000 & & .000 & .000 \\
\hline & $\mathrm{N}$ & 30 & 30 & 30 & 30 \\
\hline \multirow[t]{3}{*}{ BelKarinBOmurlariKL1L5 } & Pearson Correlation & $.757^{\prime \prime}$ & $866^{\prime \prime}$ & 1 & .783 \\
\hline & Sig. (2-tailed) & .000 &, 000 & & .000 \\
\hline & N & 30 & 30 & 30 & 30 \\
\hline \multirow[t]{3}{*}{ Kaburgak } & Pearson Correlation & $965^{\prime \prime}$ & .724 & $.783^{\circ}$ & 1 \\
\hline & Sig. (2-tailed) & .000 & .000 & .000 & \\
\hline & $\mathrm{N}$ & 30 & 30 & 30 & 30 \\
\hline
\end{tabular}

**Korelasyon 0.01 düzeyinde anlaml (2 yönde)

Batın-pelvis bölgesi kırıklarını belirlemek amacıyla pelvis ve bel-karın omurları birlikte incelenmiştir. Yedi bireyde pelvis kırıkları ( $\mathrm{n}=30, \% 23.3)$ (Şekil 1) ve altı bireyde L1-L5 bel/karın omurlarında kırılmalar/kopmalar $(\mathrm{n}=30, \% 20)$ (Şekil 2) görülmüştür. Hem pelvis kırıklarının hem de L1-L5 kırık/kopmalarının birlikte bulunduğu vaka sayısı ikidir ( $\mathrm{n}=30, \% 6.7)$. Bu iki bölgedeki kırıkların vakalar arası korelasyon ilişkisine bakıldığında, batınpelvis bölgesi ile pelvis kırıkları arasında çok yüksek pozitif bir ilişki olduğu görülmüştür $(\mathrm{r}(28)=.959, \mathrm{p}=0.000)$ (Tablo 4). Batın-pelvis bölgesinin analiz sonuçları, 7 bireyin batın-pelvis bölgesinde en çok görülen kırıkların pelvis kırıkları olduğunu göstermektedir.

Etraf bölgesi içerisinde olan bacak-ayak kırık/çıkıklar1 5 bireyde ( $\mathrm{n}=30, \% 16.7)$, kol-el kırık/çıkıkları 4 bireyde ( $\mathrm{n}=30, \% 13.3)$ tespit edilmiştir (Şekil 2). Bunların k1rıkların birbirileri ile korelasyon ilişkisi Tablo 5'de sunul- muştur. Bu korelasyon sonuçları, en yüksek korelasyonun kol bölgesinde olduğunu göstermiştir. Etraf bölgesindeki kemik kırıklarının birbirileri ile uyumluluk korelasyonlarının düşük sonuçlar verdiği görülmüştür. Bu bölgeden alınan sonuçların diğer bölgelere kıyasla daha az uyumluluk göstermesinin nedeninin, büyük ihtimalle bu bölgelerin $\mathrm{BT}$ verilerindeki eksiklikten dolayı tespit edilemeyen kırıklardan kaynaklanmış olduğu düşünülmektedir.

Tablo 4. Batın-pelvis bölgesi kemik kırıkları korelasyon tablosu.

\begin{tabular}{|ll|r|r|r|}
\hline & PelvisK & BatıPelvisBK & $\begin{array}{r}\text { BelKarinBOm } \\
\text { urlariKL1 15 }\end{array}$ \\
\hline PelvisK & Pearson Correlation & 1 & $.959^{\prime \prime}$ & $.542^{\prime \prime}$ \\
& Sig. (2-tailed) & & .000 & .002 \\
& $\mathrm{~N}$ & 30 & 30 & 30 \\
\hline BatınPelvisBK & Pearson Correlation & $.959^{\prime \prime}$ & 1 & $.463^{\prime \prime}$ \\
& Sig. (2-tailed) &, 000 & & .010 \\
& $\mathrm{~N}$ & 30 & 30 & 30 \\
\hline BelKarinBOmurlariKL1L5 & Pearson Correlation & $.542^{\prime \prime}$ & $.463^{\prime \prime}$ & 1 \\
& Sig. (2-tailed) & .002 & .010 & \\
& $\mathrm{~N}$ & 30 & 30 & 30 \\
\hline
\end{tabular}

**Korelasyon 0.01 düzeyinde anlamlı (2 yönde)

Tablo 5. Etraf bölgesi kemikleri kırıkları korelasyon tablosu.

\begin{tabular}{|c|c|c|c|c|c|}
\hline & & EtrafBK & KollardaK & Ellerdek & Bacaklardak \\
\hline \multirow[t]{3}{*}{ EtrafBK } & Pearson Correlation & 1 & $.849^{\prime \prime}$ & $.500^{\prime \prime}$ & $.589^{\circ}$ \\
\hline & Sig. (2-tailed) & & .000 & .005 & ,001 \\
\hline & N & 30 & 30 & 30 & 30 \\
\hline \multirow[t]{3}{*}{ Kollardak } & Pearson Correlation & $849^{\prime \prime}$ & 1 & $.458^{\circ}$ & .442 \\
\hline & Sig. (2-tailed) & ,000 & & ,011 & .014 \\
\hline & $\mathrm{N}$ & 30 & 30 & 30 & 30 \\
\hline \multirow[t]{3}{*}{ Ellerdek } & Pearson correlation & $.500^{\circ 1}$ & $.458^{\circ}$ & 1 &,- 131 \\
\hline & Sig. (2-tailed) & 005 & 011 & & 491 \\
\hline & $\mathrm{N}$ & 30 & 30 & 30 & 30 \\
\hline \multirow[t]{3}{*}{ Bacaklardak } & Pearson Correlation & $.589^{\prime \prime}$ & $.442^{\circ}$ &,- 131 & 1 \\
\hline & Sig. (2-tailed) & ,001 & .014 & .491 & \\
\hline & $\mathrm{N}$ & 30 & 30 & 30 & 30 \\
\hline
\end{tabular}

*Korelasyon 0.05 düzeyinde anlamlı (2 yönde)

**Korelasyon 0.01 düzeyinde anlamll (2 yönde)

$\mathrm{Bu}$ çalışmada incelenen örneklem grubunda kırıkların en az görüldüğü kemikler C1-C7 boyun omurları olmuştur. Bu bölgedeki kırıklar sadece bir bireyde $(n=30$, \%3.3), ip ile ası eylemi vakasında, ipin boyun bölgesine uyguladığı kuvvetten ötürü servikal kemiklerde oluşan künt kırıklar şeklinde gözlemlenmiştir.

Kemik kırıklarının sayısı ve kemiklere göre dağılımı belirlendikten sonra, her vakadaki künt travma ve ateşli silah travmasına bağlı kırık özellikleri ayrı ayrı incelenmiş, tüm kırıklar gösterdikleri özelliklere göre gruplara ayrılmış ve aralarındaki korelasyon ilişkileri incelenmiştir. Künt travmaya bağlı 26 ölüm olgusunda 5 çeşit kırılma özelliği saptanmıştır. Bunlar; lineer kırıklar, parçalı/çoklu kırıklar, çökme kırıkları, açık/ayrık kırıklar ve kopma kırıkları şeklinde gözlemlenmiştir. Bu beş kırık özelliği arasındaki korelasyon ilişkisi test edildiğinde, bu öldürücü nitelikteki kırıkların birbirileri ile arasında yük- 
sek korelasyonlar gözlemlenmiştir (Tablo 6).

Tablo 6. Künt travma kırık özellikleri korelasyon tablosu

\begin{tabular}{|c|c|c|c|c|c|c|}
\hline & & Lineerk & Parcalicokluk & Cokmek & AclkAyrikK & Kopmak \\
\hline \multirow[t]{3}{*}{ Lineerk } & Pearson Correlation & 1 & .304 & $.482^{\prime \prime}$ & .352 & $\overline{421}$ \\
\hline & Sig. (2-tailad) & & .102 & .007 & .056 & .021 \\
\hline & $\mathrm{N}$ & 30 & 30 & 30 & 30 & 30 \\
\hline \multirow[t]{3}{*}{ Parcalicokluk } & Pearson Correlation & .304 & 1 & $753^{\prime \prime}$ & $895^{\circ}$ & $.768^{11}$ \\
\hline & Sig. (2-tailed) & .102 & & .000 & ,000 & .000 \\
\hline & $\mathrm{N}$ & 30 & 30 & 30 & 30 & 30 \\
\hline \multirow[t]{3}{*}{ CokmeK } & Pearson Correlation & $482^{\prime \prime}$ &, $753^{\prime \prime}$ & 1 & $.707^{\prime \prime}$ & $554^{4 \prime}$ \\
\hline & Sig. (2-tailed) &, 007 & ,000 & & .000 &, 002 \\
\hline & $\mathrm{N}$ & 30 & 30 & 30 & 30 & 30 \\
\hline \multirow[t]{3}{*}{ AcikAyrikK } & Pears on Correlation & .352 & .895 & $.707^{\circ}$ & 1 & .694 \\
\hline & Sig. (2-tailed) & .056 & .000 & .000 & & .000 \\
\hline & $\mathrm{N}$ & 30 & 30 & 30 & 30 & 30 \\
\hline \multirow[t]{3}{*}{ Kopmak } & Pearson Correlation & .421 & $768^{\prime \prime}$ & $.554^{4}$ & .694 & 1 \\
\hline & Sig. (2-tailed) & .021 & .000 & .002 &, 000 & \\
\hline & $\mathrm{N}$ & 30 & 30 & 30 & 30 & 30 \\
\hline
\end{tabular}

*Korelasyon 0.05 düzeyinde anlamlı (2 yönde)

**Korelasyon 0.01 düzeyinde anlamlı (2 yönde)

Ateşli silah yaralanmasına bağlı 2 ölüm olgusunda beş çeşit kırılma özelliği gözlemlenmiştir. Bunlar; giriş/ çıkış deliğine ait kırıklar, lineer kırık, konsantrik kırık, parçalı/çoklu kırık, ve açık/ayrık kırıklar şeklindedir. Bu kırıklar arasında yapılan korelasyon analizleri içerisinde giriş-çıkış delikleri ile konsantrik kırıklar arasında çok yüksek pozitif bir ilişki tespit edilmiştir. Parçalı çoklu k1rıklar ile açık ayrık kırıklar arasında da yüksek pozitif bir ilişki olduğu görülmektedir (Tablo 7). Bu kırıkların analizleri yüksek sonuçlar verse de vaka sayısının 2 olması, farklı kırık özelliklerinin tespiti ve karşılaştırma çalışmaları açısından bir dezavantaj olmuştur. Yine de sonuç ola- rak, ateşli silah yaralanması nedeniyle kemikler üzerinde görülen kırılma özelliklerinin, her iki vakada birbirileri ile çok yüksek uyumluluk gösterdiği gözlemlenmiştir.

BT analizleri sonucunda tespit edilen kırıkların gösterdikleri özelliklere göre, her vaka için travma çeşidi tanımlaması yapılmış ve bulgular adli antropolojik rapor olarak sunulmuştur. Tüm bulgular daha sonra adli otopsi raporlarında belirtilen travma çeşidi tanımlamaları ile karşılaştırılmış ve bulguların uyumlulukları test edilmiştir. Bu karşılaştırma sonucunda, 30 vakanın 27'sinin eşleşmiş olduğu görülmüştür $(\mathrm{n}=30, \% 90)$ (Tablo 8). Eşleşmeyen vakaların bir tanesi (Vaka no.10) BT verisi yetersizliğinden, bir tanesi (Vaka no.27) birey üzerinde kırık bulgusu olmamasından, bir tanesi de (Vaka no.25) adli antropolojik analiz esnasında tespit edilen boyun omurları kırıklarının otopsi esnasında tespit edilmemiş olmasından kaynaklanmıştır. Adli antropolojik analizler sonucunda her vaka için ölüme sebebiyet veren mekanizmanın tespiti yapılmıştır. Bu tespitler, otopsi raporlarındaki ölüm sebebi tanımlamalarıyla karşılaştırılmış ve sonuçlar Tablo 9'da sunulmuştur. Bu tabloya göre, 30 vakanın 22'nde tam uyumluluk (\%73.3) görülmüştür. 2-5, 7,9, 11-24, 29, 30 numaralı vakalarda, adli antropolojik analizler sonucu belirlenen ölüm sebebiyet veren mekanizma tanımlamaları ile adli otopsi raporunda belirtilen ölüm nedeni tanımlamalarındaki bulguların eşleştiği görülmüştür. 4 vakada (Vaka no 1, 6, 26 ve 28) belirlenemeyen travmaların kafa (Vaka no.1) ve gögüs bölgelerinde olduğu gözlemlenmiştir (Vaka no.6, 26, 28).

Tablo 7. Ateşli Silah Travması kırık özellikleri korelasyonu tablosu.

\begin{tabular}{|c|c|c|c|c|c|c|}
\hline & & $\begin{array}{l}\text { GirisCikisDeli } \\
\text { gi }\end{array}$ & Lineerk & KonsantrikK & Parcalicokluk & AcikAyrikk \\
\hline \multirow[t]{3}{*}{ GirisCikisDeligi } & Pearson Correlation & 1 & $.680^{\circ \prime}$ & $1,000^{\prime \prime}$ & 691 & .671 \\
\hline & Sig. (2-tailed) & & .000 & .000 & .000 & .000 \\
\hline & $N$ & 30 & 30 & 30 & 30 & 30 \\
\hline \multirow[t]{3}{*}{ Lineerk } & Pearson Correlation & $.680^{\prime \prime}$ & 1 & $.680^{\prime \prime}$ & 304 & .352 \\
\hline & Sig. (2-tailed) &, 000 & &, 000 & .102 &, 056 \\
\hline & $N$ & 30 & 30 & 30 & 30 & 30 \\
\hline \multirow[t]{3}{*}{ KonsantrikK } & Pearson Correlation & $1,000^{\prime \prime}$ & $.680^{\prime \prime}$ & 1 & $691^{11}$ & $.671^{11}$ \\
\hline & Sig. (2-tailed) & .000 & .000 & & .000 & .000 \\
\hline & $N$ & 30 & 30 & 30 & 30 & 30 \\
\hline \multirow[t]{3}{*}{ ParcaliCokluk } & Pearson Correlation & $.691^{\prime \prime}$ & .304 & $.691^{\prime \prime}$ & 1 & $.895^{\prime \prime}$ \\
\hline & Sig. (2-tailed) &, 000 & , 102 &, 000 & & .000 \\
\hline & $N$ & 30 & 30 & 30 & 30 & 30 \\
\hline \multirow[t]{3}{*}{ AcikAyrikK } & Pearson Correlation & 671 & .352 & .671 & $.895^{\prime \prime}$ & 1 \\
\hline & Sig. (2-tailed) & .000 &, 056 & .000 & .000 & \\
\hline & $N$ & 30 & 30 & 30 & 30 & 30 \\
\hline
\end{tabular}

*Korelasyon 0.05 düzeyinde anlamlı (2 yönde)

**Korelasyon 0.01 düzeyinde anlamlı (2 yönde) 
Tablo 8. Travma çeşidi bulguları karşılaştırılması.

\begin{tabular}{|c|c|c|}
\hline Vaka & Adli Antropolojik Bulgu & Adli Otopsi Bulgusu \\
\hline 1 & Künt & Künt \\
\hline 2 & Künt & Künt \\
\hline 3 & Künt & Künt \\
\hline 4 & Künt & Künt \\
\hline 5 & Künt & Künt \\
\hline 6 & Künt & Künt \\
\hline 7 & Künt & Künt \\
\hline 8 & Künt & Künt \\
\hline 9 & Künt & Künt \\
\hline 10 & $\begin{array}{c}\text { BT verileri yetersiz } \\
\text { olduğundan tespit edilemedi. }\end{array}$ & Künt \\
\hline 11 & Künt & Künt \\
\hline 12 & Künt & Künt \\
\hline 13 & Künt & Künt \\
\hline 14 & Künt & Künt \\
\hline 15 & Künt & Künt \\
\hline 16 & Künt & Künt \\
\hline 17 & Künt & Künt \\
\hline 18 & Künt & Künt \\
\hline 19 & Ateşli silah & Ateşli silah \\
\hline 20 & Ateşli silah & Ateşli silah \\
\hline 21 & Künt & Künt \\
\hline 22 & Künt & Künt \\
\hline 23 & Künt & Künt \\
\hline 24 & Künt & Künt \\
\hline 25 & Künt & $\begin{array}{c}\text { Ası eylemi sonucu oluşan } \\
\text { solunum yolları kapanması } \\
\text { ve gelişen asfiksi (havasızlık) }\end{array}$ \\
\hline 26 & Künt & Künt \\
\hline 27 & $\begin{array}{l}\text { Kemikler üzerinde tespit } \\
\text { edilen bir travma bulgusu } \\
\text { bulunmamaktadır. }\end{array}$ & Pulmoner emboli \\
\hline 28 & Künt & Künt \\
\hline 29 & Künt & Künt \\
\hline 30 & Künt & Künt \\
\hline
\end{tabular}

\section{Tartışma}

$\mathrm{Bu}$ çalışmaya benzer çalışmaların genellikle postmortem X-Ray, BT ve MRI verileri kullanılarak yapıldığ 1 ve travma tespitleri için çoğunlukla patologların görev aldıkları bilinmektedir (14-19). Özellikle New Mexico Üniversitesi CFI bölümünde yapılan çalışmalar, otopsi ile belirlenen ölüm nedenlerinin postmortem BT ve MRI verilerinin kullanılarak belirlenip belirlenemeyeceğinin değerlendirilmesi üzerinedir (18). Bu araştırmanın diğerlerinden farkı, travmalara bağlı kırıkların ölümle olan ilişkilerinin belirlenebilmesi için bireylerin BT verilerinin perimortem süreçte, yani ölüm öncesinde çekilmiş olması ve analizlerin bir fizik antropolog tarafından gerçekleşti- rilmiş olmasıdır. Diğer araştırmalarda bireyler öldükten sonra BT'leri çekilirken, bu araştırmada Vaka 25 hariç (ip ile ası eylemi), bireyler BT çekimleri esnasında hala yaşamaktadırlar. Bu çalışmada bu yolun izlenmesinin nedeni, bireylerin iskeletlerinde tespit edilen travma bulgularının ölüm öncesi ve sonrası süreç içerisindeki (perimortem) durumlarını incelemek, bireylerin hayati fonksiyonlarını nasıl etkilediklerini gözlemlemek ve hangi durumlarda ölüme sebebiyet verdiklerini tespit etmektedir.

Travmatik vakaların cinsiyete bağlı değişkenliğini inceleyen çalışmalarda, bu çalışmada olduğu gibi, erkek olguların sayısının kadınlardan daha fazla olduğu bildirilmiştir $(4,18,20,21)$. Ölüm olgularının en çok görüldüğü yaş aralığının 21-30 yaşlar olarak belirlenmesine benzer bir durum Eskişehir Osmangazi Üniversitesinde, 306 adli raporun incelenerek kemik kırıklarının değerlendirildiği bir çalışmada da aynı şekilde rapor edildiği görülmüştür (4). Bu çalışma esnasında tespit edilen travma çeşitleri ile, cinsiyet ve yaş grupları arasında anlamlı bir ilişki bulunmadığ 1 gözlemlenmiştir. İnsan kemiklerindeki k1rıkların incelendiği çalışmalarda, kemik kırıklarının en çok görüldüğü vakaların trafik kazaları olduğu rapor edilmektedir $(4,18,22-26)$. Bu araştırmadaki vakaların da $\% 60$ 'nı trafik kazaları oluşturmaktadır. Benzer bazı çalışmalarda da, bu çalışmada olduğu gibi yüksekten düşme vakalarının, trafik kazalarından sonra kemik kırıklarının en s1k görüldüğü travmaya bağl1 ölüm olguları olduğundan bahsedilmektedir (26).

Araştırmanın sonuçlarında, kemik kırıklarının en çok görüldüğü bölge kafa kemikleri olarak belirlenmiştir. Travmaya bağlı ölümler üzerine yapılan çalışmalarda kafa bölgesi kırıklarının ölümle olan yakın ilişkisi sıklıkla rapor edilmektedir $(4,27,28)$. Dört olguda (Vaka no.1, 5, 23, 29) BT analizlerinde kafatasında kırık bulgusuna rastlanmamasına rağmen bireylerin adli otopsi raporlarında künt kafa travmasından bahsedilmektedir. Bu bulguya benzer çalışmalar incelendiğinde, kafa travmasına bağlı beyin kanamalarının gerçekleşmesi için kafa kırıklarına her zaman gerek olmadığının rapor edildiği görülmektedir (28). Üç vakada (No.5, 23, 29) kafa bölgesinde kırık bulgusu olmamasına rağmen, virtopsi sırasında kafatası içinde görülen minik kemik parçalarından dolayı bu bireylerin muhtemel bir kafatası travması yaşamış olduklarını düşündürmüş ve adli antropolojik raporlarda muhtemel kafatası travması şeklinde bahsedilmiştir.

İstatistiksel sonuçlar, kafatası kırıklarından sonra ölüme en çok sebebiyet veren kırıkların, göğüs bölgesinde görüldüğünü göstermiştir. Bu bölgede tespit edilen k1rıkların, bireylerin hayati fonksiyonlarını ağır derecede etkiledikleri ve en az kafatası kırıkları kadar ölüme neden oldukları sadece bu çalışmada değil benzer araştır- 
Tablo 9. Ölüm sebebi tahminleri ve ölüm sebebi raporu bulguları karşılaştırma tablosu.

\begin{tabular}{|c|c|c|}
\hline Vaka & $\begin{array}{l}\text { Adli Antropolojik Analizlere Göre Ölüm Sebebi } \\
\text { Tahmini }\end{array}$ & Adli Otopsi Raporuna Göre Ölüm Sebebi \\
\hline 1 & $\begin{array}{l}\text { Künt göğüs travmasına bağlı çoklu kaburga kırıkları, } \\
\text { omurga kırıkları (göğüs-karın bölgesi), etraf bölgesi } \\
\text { kırıklarına bağlı olduğu tahmin edilmektedir. }\end{array}$ & $\begin{array}{l}\text { Künt kafa, göğüs ve karın travması sonucu gelişen kafa ve kaburga } \\
\text { kemikleri kırıkları, beyin kanaması, iç organ (sağ akciğer ve dalak) } \\
\text { ve iç kanama. }\end{array}$ \\
\hline 2 & $\begin{array}{l}\text { Künt göğ̈̈s travmasına bağlı çoklu kaburga kırıkları } \\
\text { ile birlikte batın-pelvis bölgesi kırıklarına bağlı } \\
\text { olduğu tahmin edilmektedir. }\end{array}$ & $\begin{array}{l}\text { Künt kafa, göğüs ve batın travması sonucu oluşan, beyin kanaması } \\
\text { (subdural ve subaraknoidal), çoklu kaburga kırkları, iç organ } \\
\text { yaralanması (her iki akciğer, karaciğer, dalak) ve iç kanama (göğüs- } \\
\text { karın boşlukları). }\end{array}$ \\
\hline 3 & $\begin{array}{l}\text { Künt travmaya bağlı kafatası kırıkları ve omurga } \\
\text { (göğüs-karın bölgesi) kırıklarına bağlı olduğu } \\
\text { tahmin edilmektedir. }\end{array}$ & $\begin{array}{l}\text { Künt kafa, göğüs ve karın travması sonucu oluşan kafa kemikleri } \\
\text { kırığı, beyin kanaması, iç organ yaralanması (her iki akciğer). }\end{array}$ \\
\hline 4 & $\begin{array}{l}\text { Künt travmaya bağlı göğüs bölgesinde çoklu } \\
\text { kaburga kırıkları ve etraf bölgesi kırıklarına bağlı } \\
\text { olduğu düşünülmektedir. }\end{array}$ & $\begin{array}{l}\text { Künt göğüs ve karın travması sonucu gelişen çoklu kaburga } \\
\text { kırıkları, iç organ (her iki akciğer, karaciğer) yaralanması ve iç } \\
\text { kanama (iki taraflı hemotoraks, batın ve pelvis içi kanama) }\end{array}$ \\
\hline 5 & $\begin{array}{l}\text { Künt travmaya bağlı çoklu kaburga kırıkları ve } \\
\text { pelvis kırıklarına bağlı olduğu tahmin edilmektedir. } \\
\text { Kafatasında kırık bulgusu yoktur, fakat BT } \\
\text { görüntülerinde kafatası içerisinde tespit edilen } \\
\text { minik kemik parçaları muhtemel kafa travmasına } \\
\text { işaret etmektedir. }\end{array}$ & $\begin{array}{l}\text { Künt kafa, göğüs ve karın travması sonucu gelişen çoklu } \\
\text { kaburga kemikleri ve pelvis kemikleri kırıkları, beyin kanaması } \\
\text { (subaraknoidal), iç organ (sol akciğer, karaciğer) yaralanması ve } \\
\text { iç kanama (iki taraflı hemotoraks, batın içi ve pelvis içi kanama) }\end{array}$ \\
\hline 6 & $\begin{array}{l}\text { Künt travmaya bağlı kafatası kırıklarına bağlı } \\
\text { olduğu tahmin edilmektedir. }\end{array}$ & $\begin{array}{l}\text { Künt kafa ve gögüs travması sonucu gelişen kafa kemikleri parçalı } \\
\text { kırıkları, beyin kanaması ve doku hasarı ile iç organ yaralanması } \\
\text { (her iki akciğer) }\end{array}$ \\
\hline 7 & $\begin{array}{l}\text { Künt travmaya bağlı göğüs bölgesinde çoklu } \\
\text { kaburga kırıkları, batın-pelvis kırıkları ve etraf } \\
\text { bölgesi çoklu kırıklarına bağlı olduğu tahmin } \\
\text { edilmektedir. }\end{array}$ & $\begin{array}{l}\text { Künt göğüs ve karın ile pelvis travması sonucu oluşan çoklu } \\
\text { kaburga kemikleri kırıkları, pelvis kırıkları, iç organ yaralanması } \\
\text { (sol akciğer, dalak, karaciğer ve mezenter) }\end{array}$ \\
\hline 8 & $\begin{array}{l}\text { BT görüntüleri yetersiz olduğundan tahmin } \\
\text { yapılmadı. }\end{array}$ & $\begin{array}{l}\text { Künt kafa ve göğüs travması sonucu gelişen kafa kemiği kırı̆̆ı, } \\
\text { beyin kanaması ve beyin ödemi, çoklu kaburga kemikleri kırıkları, } \\
\text { iç organ (her iki akciğer). }\end{array}$ \\
\hline 9 & $\begin{array}{l}\text { Künt travmaya bağlı kafatası, göğüs (kaburga- } \\
\text { omurga) ve pelvis kırıklarına bağlı olduğu tahmin } \\
\text { edilmektedir. }\end{array}$ & $\begin{array}{l}\text { Künt kafa, göğüs ve karın ile pelvis travması sonucu oluşan parçalı } \\
\text { kafa kemikleri kırıkları, beyin kanaması ve beyin doku hasarı, iç } \\
\text { organ yaralanması (her iki akciğer) ve iç kanama (karın ön, arka } \\
\text { duvar, pelvis içi) }\end{array}$ \\
\hline 10 & $\begin{array}{l}\text { BT görüntüleri yetersiz olduğundan tahmin } \\
\text { yapılmadı. }\end{array}$ & $\begin{array}{l}\text { Künt kafa, göğüs ve göğüs travması sonucu oluşan beyin kanaması } \\
\text { ile iç organ yaralanması (akciğerler ve dalak) ve iç kanama (göğü } \\
\text { ve karın boşluklarına). }\end{array}$ \\
\hline 11 & $\begin{array}{l}\text { Künt travmaya bağlı kafatası bölgesi kırıkları, } \\
\text { göğüs (kaburga-omurga-skapula) bölgesi kırıkları } \\
\text { ve etraf bölgesi kırıklarına bağlı olduğu tahmin } \\
\text { edilmektedir. }\end{array}$ & $\begin{array}{l}\text { Künt kafa, göğüs ve karın travması sonucu gelişen kafa ve kaburga } \\
\text { kemikleri kırıkları, beyin kanaması, iç organ (sağ akciğer ve dalak) } \\
\text { ve iç kanama. }\end{array}$ \\
\hline 12 & $\begin{array}{l}\text { Künt travmaya bağlı göğüs ve karın bölgesi } \\
\text { kemikleri kırıkları, pelvis-batın bölgesi çoklu } \\
\text { kırıklarına bağlı olduğu tahmin edilmektedir. }\end{array}$ & $\begin{array}{l}\text { Künt gögüs ve karın ile pelvis travması sonucu oluşan sol ön kol } \\
\text { ampütasyonu (büyük damar yaralanması), pelvis kırıkları, iç organ } \\
\text { yaralanması (sağ akciğer, dalak, karaciğer) }\end{array}$ \\
\hline 13 & $\begin{array}{l}\text { Künt travmaya bağlı kafa ve göğüs (kaburga) } \\
\text { kırıkları ile etraf bölgesi kırıklarına bağlı olduğu } \\
\text { tahmin edilmektedir. }\end{array}$ & $\begin{array}{l}\text { Genel vücut travması (künt kafa, göğüs, karın ve ekstremite } \\
\text { travması) sonucu oluşan çoklu kaburga ve uzun kemik kırıkları ve } \\
\text { beyin ödemi }\end{array}$ \\
\hline 14 & $\begin{array}{l}\text { Künt travmaya bağlı göğüs bölgesi (kaburga- } \\
\text { sternum) ve omurga (L1-L5) çoklu kırıklarına bağlı } \\
\text { olduğu tahmin edilmektedir. }\end{array}$ & $\begin{array}{l}\text { Künt göğüs travması sonucu gelişen çoklu kaburga kemikleri ve } \\
\text { sternum kemiği kırığı ile iç organ yaralanması ve iç kanama }\end{array}$ \\
\hline
\end{tabular}


Tablo 9. Ölüm sebebi tahminleri ve ölüm sebebi raporu bulguları karşılaştırma tablosu.

\begin{tabular}{|c|c|c|}
\hline 15 & $\begin{array}{l}\text { Künt travmaya bağlı kafa kırıkları ve göğüs bölgesi } \\
\text { (skapula-klavikula) kırıklarına bağlı olduğu tahmin } \\
\text { edilmektedir. }\end{array}$ & $\begin{array}{l}\text { Künt kafa ve göğüs travması sonucu gelişen kafa kemikleri } \\
\text { kırıkları, beyin kanaması, beyin doku yaralanması ve beyin ödemi }\end{array}$ \\
\hline 16 & $\begin{array}{l}\text { Künt travmaya bağlı omurga bölgesi (bel- } \\
\text { karın bölgesi) kırıklarına bağlı olduğu tahmin } \\
\text { edilmektedir. }\end{array}$ & $\begin{array}{l}\text { Künt kafa, göğüs ve karın travması sonucu gelişen beyin kanaması, } \\
\text { iç organ (her iki akciğer ve dalak) ve büyük damar yaralanması, iç } \\
\text { (batın içi) ve dış kanama. }\end{array}$ \\
\hline 17 & $\begin{array}{l}\text { Künt travmaya bağlı, kafa, göğ̈̈s ve omurga (bel- } \\
\text { karın) bölgesi kırıklarına bağlı olduğu tahmin } \\
\text { edilmektedir. }\end{array}$ & $\begin{array}{l}\text { Künt kafa, göğüs ve karın travması sonucu gelişen kafa kemikleri } \\
\text { kırıkları, beyin kanamaları ve beyin doku yaralanması, iç organ } \\
\text { (her iki akciğer, beyin, karaciğer ve dalak) ve iç (batın içi) kanama }\end{array}$ \\
\hline 18 & $\begin{array}{l}\text { Künt travmaya bağlı çoklu kafatası kırıklarına bağlı } \\
\text { olduğu tahmin edilmektedir. }\end{array}$ & $\begin{array}{l}\text { Künt kafa travması sonucu gelişen kafa kemikleri kırıkları, beyin } \\
\text { doku yaralanması ve beyin kanaması }\end{array}$ \\
\hline 19 & $\begin{array}{l}\text { Ateşli silah travmasına bağl1, bir adet giriş ve çıkış } \\
\text { deliği bulgusuna bağlı olduğu tahmin edilmektedir. }\end{array}$ & $\begin{array}{l}\text { Kişinin vücudunda } 1 \text { adet ASMÇ giriş ve çıkış yarsı olup tek başına } \\
\text { öldürücü niteliktedir. Bitişik atış. }\end{array}$ \\
\hline 20 & $\begin{array}{l}\text { Ateşli silah travmasına bağlı, kafatasında tespit } \\
\text { edilen } 1 \text { giriş-çıkış deliği ve göğ̈̈s bölgesinde (T4) } \\
\text { tespit edilen } 1 \text { giriş-çıkış deliğine bağlı olduğu } \\
\text { tahmin edilmektedir. Sakrum bölgesinde vücutta } \\
\text { mevcut halde tespit edilen } 1 \text { mermi çekirdeği } \\
\text { mevcuttur (min. 3). }\end{array}$ & $\begin{array}{l}\text { Ateşli silah yaralanması sonucu oluşan, kafa kemikleri kırıkları, } \\
\text { beyin doku yaralanması, iç organ yaralanması (sağ akciğer, uterus } \\
\text { ve kolon) ve iç kanama (göğüs sağ boşluğuna) (min.5) }\end{array}$ \\
\hline 21 & $\begin{array}{l}\text { Künt travmaya bağlı kafa, göğüs, omurga (karın } \\
\text { bölgesi), pelvis-batın bölgesi ve etraf bölgesinde } \\
\text { tespit edilen çoklu kırıklara bağlı olduğu tahmin } \\
\text { edilmektedir. }\end{array}$ & $\begin{array}{l}\text { Künt kafa, göğüs ve karın travması sonucu gelişen kafa kemikleri } \\
\text { kırıkları, beyin doku yaralanması ve kanaması, iç organ } \\
\text { yaralanması (her iki akciğer, karaciğer, mezenter) ve iç kanama } \\
\text { (göğüs boşluklarına) }\end{array}$ \\
\hline 22 & $\begin{array}{l}\text { Künt travmaya bağlı kafatası kırıklarına bağlı } \\
\text { olduğu tahmin edilmektedir. }\end{array}$ & $\begin{array}{l}\text { Künt kafa travması sonucu gelişen kafa kemikleri kırıkları, beyin } \\
\text { doku yaralanması ve beyin kanaması }\end{array}$ \\
\hline 23 & $\begin{array}{l}\text { Künt travmaya bağlı omurga (karın bölgesi) ve } \\
\text { batın-pelvis bölgesi kırıklarına bağlı olduğu tahmin } \\
\text { edilmektedir. Kafatasında kırıkbulgusu yoktur,fakat } \\
\text { BT görüntülerinde kafatası içerisinde tespit edilen } \\
\text { minik kemik parçaları muhtemel kafa travmasına } \\
\text { işaret etmektedir. }\end{array}$ & $\begin{array}{l}\text { Künt kafa, göğüs ve karın travması sonucu gelişen kafa kemikleri } \\
\text { kırıkları, beyin doku yaralanması ve beyin kanaması, iç organ } \\
\text { yaralanması (her iki akciğer ve karaciğer) ve pnömotoraks }\end{array}$ \\
\hline 24 & $\begin{array}{l}\text { Künt travmaya bağlı kafatası kırıklarına bağlı } \\
\text { olduğu tahmin edilmektedir. }\end{array}$ & $\begin{array}{l}\text { Künt kafa travması sonucu gelişen kafa kemikleri kırıkları ve beyin } \\
\text { kanaması }\end{array}$ \\
\hline 25 & $\begin{array}{l}\text { Ası eylemi sonucu meydana gelen künt travmaya } \\
\text { bağlı boyun kırıklarına bağlı olduğu tahmin } \\
\text { edilmektedir. }\end{array}$ & $\begin{array}{l}\text { Ası eylemi sonucu oluşan solunum yolları kapanması ve gelişen } \\
\text { asfiksi (havasızlık) }\end{array}$ \\
\hline 26 & $\begin{array}{l}\text { Künt travmaya bağlı kafatas kırıklarına bağ }{ }_{1} \\
\text { olduğu tahmin edilmektedir. }\end{array}$ & $\begin{array}{l}\text { Künt kafa, göğüs ve karın travması sonucu gelişen kafa kemikleri } \\
\text { kırıkları, beyin kanaması, beyin doku yaralanması, iç organ } \\
\text { yaralanması (akciğerler ve karaciğer) }\end{array}$ \\
\hline 27 & $\begin{array}{l}\text { Kemikler üzerinde tespit edilen bir travma bulgusu } \\
\text { yoktur. Ölüm sebebinin kemik kırıklarına bağlı } \\
\text { olmadığı tahmin edilmektedir. }\end{array}$ & Pulmoner emboli \\
\hline 28 & $\begin{array}{l}\text { Künt travmaya bağlı kafatası kırıklarına bağlı } \\
\text { olduğu tahmin edilmektedir. }\end{array}$ & $\begin{array}{l}\text { Künt kafa ve göğüs travması sonucu gelişen kafa kemikleri } \\
\text { kırıkları, beyin kanaması ve beyin ödemi }\end{array}$ \\
\hline 29 & $\begin{array}{l}\text { Künt travmaya bağlı omurga kırıkları bağlı olduğu } \\
\text { tahmin edilmektedir. Kafatasında kırı bulgusu } \\
\text { yoktur, fakat BT görüntülerinde kafatası içerisinde } \\
\text { tespit edilen minik kemik parçaları muhtemel kafa } \\
\text { travmasina işaret etmektedir. }\end{array}$ & $\begin{array}{l}\text { Künt kafa travması sonucu gelişen beyin kanamaları (subdural ve } \\
\text { subaraknoidal) }\end{array}$ \\
\hline 30 & $\begin{array}{l}\text { Künt travmaya bağlı kafatası kırıkları, göğüs } \\
\text { bölgesinde çoklu kaburga-omurga kırıklarına bağlı } \\
\text { olduğu tahmin edilmektedir. }\end{array}$ & $\begin{array}{l}\text { Künt kafa ve göğüs travması sonucu gelişen kafa kemiği kırıkları, } \\
\text { beyin kanaması, çoklu kaburga kemikleri kırıkları }\end{array}$ \\
\hline
\end{tabular}


malarda da sıklıkla bahsedilmektedir $(26,29,30)$. Göğüs bölgesinde tespit edilen kırıkların en çok kaburgalarda görülmüş olması, kaburga kırıklarının detaylı incelendiği çalışmalarda çoklu kaburga kırıklarının bireylerin hayati fonksiyonlarını yüksek derecede etkilediğinden bahsedilmektedir $(30,31)$. Bu araştırmada belirlenen göğüs omurlarındaki kırıkların, kaburga kırıkları ile yüksek pozitif ilişki, Sirmali ve arkadaşlarının (31) torasik travmaları ile kaburga kırıklarını birlikte inceledikleri çalışmalarında da benzer şekilde rapor edilmiştir. Göğüs bölgesi ile bel-karın bölgesi omurları kırıklarının birlikte görülmesi, bu araştırmada da olduğu gibi, genellikle motosiklet kazalarında karşımıza çıkmaktadır (32). Göğüs bölgesi kırıklılarının, omurga kırıkları ile birlikte görüldüğü vakalarda, bu kırıkların bireylerin hayati fonksiyonlarını ağır derecede etkiledikleri birçok araştırmacı tarafından da bahsedilmektedir $(14,26,31)$.

İp ile as1 eylemi olgusunda (Vaka 25), adli antropolojik analizlerde tespit edilen boyun omurları kırıklar1nın adli otopsi raporunda yer almamasının nedeni otopsi esnasında boyun omurlarındaki korpus kırıklarının tespitinde yaşanan zorluklardan kaynaklandığı anlaşılmıştır. Adli antropolojik analizler esnasında kemikler, BT görüntülerinden üç boyutlu olarak incelenebilmekte ve etraflarında yumuşak doku olmadan daha net bir şekilde görüntülenebilmektedir (14-19). Adli otopsilerde boyun kemikleri her ne kadar inceleniyor olsa da, etraflarındaki yumuşak doku yoğunluğundan ötürü özellikle korpus kırıkları bazen tespit edilememektedir. Örneğin Makino ve arkadaşları, boyun kırıkları olan 42 vakada postmortem BT verilerinden 74 kemik kırığını belirlediklerini ve aynı vakaların otopsilerinde bunlardan sadece 23 'nün tespit edildiğini rapor etmişlerdir (33). Bunun yanında, adli antropolojik analizler sonucunda ölüm nedeni kemik kırıklarına bağlı olmadığı tahmin edilen 27 numaralı vakanın, adli otopsi raporundaki ölüm sebebi Pulmoner Emboli olarak belirtildiği görülmüştür. Bu bulgu üzerine yapılan literatür araştırmasında, künt travmaya bağlı olarak gelişen ve kan pıhtısının damar yolunu tıkaması sonucu bireyin ölümüne neden olan bir bulgu olduğu görülmüştür (34). Bu çalışmadaki pülmoner emboli olgusu da künt travmaya bağlı olarak gelişmiş, fakat bireyin vücudunda kemik kırığına rastlanmamıştır.

İncelenen 30 olguda, künt travmaya bağlı kırıkların genelde lineer kırıklar, parçalı/çoklu kırıklar, çökme kırıkları, açık/ayrık kırıklar ve kopma kırıklardan oluştuğu; ateşli silah travmasına bağlı kırıkların giriş/çıkış delikleri, lineer kırık, parçalı/çoklu kırık, açık/ayrık kırık ve konsantrik kırıklardan meydana geldiği görülmüştür.
Bu bulgular, travma çeşidi ve kemik kırıkları özellikleri üzerine yapılan diğer çalışmalarda da aynı sıklıkta bahsedilmektedir $(6,14,17,35-49)$. Özellikle iki ateşli silah yaralanması vakasında görülen giriş-çıkış delikleri ile konsantrik kırıklar arasındaki çok yüksek pozitif ilişki ve kafatasında görülen ayrık kırıkların, benzer çalışmalarda bitişik atış veya yakın mesafeden yapılan atışlardan kaynaklanan yaralanmalarda görüldüğü rapor edilmiştir (50). Bu bulgu da, bu iki vakada görülen kırık özelliklerini ve travma mekanizmasını destekler niteliktedir.

$\mathrm{Bu}$ çalışma, adli vakalarda BT tarayıcısı ve bu verileri üç boyutlu görüntüye dönüştüren bir program ile insan iskeletlerinde travma tespiti yapılabilmesinin mümkün olduğunu göstermiştir. BT tarayıcısı ile görüntü alınan her noktada detaylı kemik analizi yapılabilmekte, kırıklar çeşitli açılardan ve üç boyutlu olarak incelenebilmektedir. Kemiklerin sadece kortikal bölgeleri değil, trabeküler bölgelerinde de incelemeler yapılabilmekte ve kırıkların süngerimsi dokuda nasıl devam ettikleri izlenebilmektedir (14). Birçok çalışmada da bahsedildiği gibi, kırıklar gösterdikleri özelliklere göre bireylerin kasıtlı veya kasıtsız olaylar neticesinde hayatlarını kaybettiklerine işaret etmektedirler (47). Bu araştırmada, kasıtlı ve kasıtsız travmaları birbirinden belirgin olarak ayıracak yeterli istatistiksel veriler bulunmamakla birlikte, kasitlı travma olarak değerlendirilebilecek 1 ip ile ası ve 2 ateşli silah vakalarındaki kırıklar kafatası ve boyunda (Vaka 19, 20, Vaka 25) görülmüştür.

Bu çalışma esnasında BT tarayıcısı ile standart otopsi prosedürü esnasında belirlenemeyen kemik travmaları da belirlenmiştir. Örneğin Vaka 1'deki sol femur çıkı̆̆ı, Vaka 4'te sağ humerus başı kopma kırı̆̆ , Vaka 11'deki sağ skapula kırığı ve sol humerus çıkığı, Vaka 17'deki sağ skapula kırığı, Vaka 21'deki lumbar omurlarında kopmalar ve sol humerus kemiğindeki koparak ayrılma, Vaka 25'deki boyun kırıkları otopsi esnasında belirlenemeyen bulgular oldukları gözlemlenmiştir. Bu bulgular, BT analizlerinin adli otopsilere katkısını açık şekilde gösterir niteliktedir $(16,18)$. Burada belirtilmesi gereken önemli nokta, üzerinde hala yumuşak doku olan bir bireyde BT kullanılarak kemiklerindeki travmaya bağlı değişikliklerin detaylı olarak incelenmesinin mümkün olduğu, fakat ölüm sebebinin net olarak belirlenebilmesi için adli otopsiye ihtiyaç duyulmasıdır. Bu sebepten dolayıdır ki, yumuşak dokuya sahip bireylerin ölüm nedeni tespitinde BT'nin tek başına değil, otopsiye yardımcı veya tamamlayıcı bir unsur olarak kesinlikle kullanılması önerilmektedir. 
Tablo 10. BT'de incelenen kemik sayısı ve tespit edilen kırık sayısı

\begin{tabular}{|c|c|c|}
\hline Vaka No & $\begin{array}{c}\text { BT'de mevcut-incelenen } \\
\text { kemik sayısı }\end{array}$ & $\begin{array}{c}\text { Tespit edilen kırık } \\
\text { kemik sayısı }\end{array}$ \\
\hline 1 & 63 & 36 \\
\hline 2 & 63 & 14 \\
\hline 3 & 50 & 3 \\
\hline 4 & 63 & 16 \\
\hline 5 & 63 & 12 \\
\hline 6 & 63 & 1 \\
\hline 7 & 63 & 13 \\
\hline 8 & 17 & 1 \\
\hline 9 & 63 & 18 \\
\hline 10 & 5 & 0 \\
\hline 11 & 63 & 7 \\
\hline 12 & 63 & 33 \\
\hline 13 & 63 & 4 \\
\hline 14 & 63 & 30 \\
\hline 15 & 59 & 3 \\
\hline 16 & 60 & 4 \\
\hline 17 & 63 & 4 \\
\hline 18 & 63 & 1 \\
\hline 19 & 2 & 1 \\
\hline 20 & 63 & 2 \\
\hline 21 & 63 & 16 \\
\hline 22 & 63 & 1 \\
\hline 23 & 63 & 3 \\
\hline 24 & 61 & 1 \\
\hline 25 & 8 & 3 \\
\hline 26 & 2 & 1 \\
\hline 27 & 61 & 0 \\
\hline 28 & 63 & 1 \\
\hline 29 & 58 & 2 \\
\hline 30 & 63 & 11 \\
\hline Toplam & 1580 & 242 \\
\hline
\end{tabular}

\section{Sonuç}

$\mathrm{Bu}$ araştırmada 30 bireye ait 1580 adet kemik incelenmiş ve 242'nde kırıklar tespit edilmiştir (Tablo 10). Adli antropolojik analizlerde, travma çeşidi tespitinde 30 vakadan 27'sinin doğru tahmin edilerek \%90 oranında bir başarı sağlandığı görülmüştür. 22 vakada tespit edilen tam uyumluluk ve 4 vakada tespit edilen yüksek yaklaşık uyumluluk göz önünde bulundurulduğunda, insan iskeletlerinden ölüm nedeni tahminlerinin \%86.6 oranında bir başarı yüzdeliğine sahip olduğu görülmektedir. Bu da demektir ki, insan kemiklerinden analiz yapılmasını gerektiren adli vakalarda vücut bölgelerine ait kemiklerin tam olması halinde adli antropolojik analizler neticesinde travma çeşidi ve buna bağlı muhtemel ölüm nedeni yüksek oranda doğru 'tahmin' edilebilmektedir. Bu çalış- mada belirlenen travma özellikleri ve tanımlamalarının, insan iskeletlerinde travma çeşidi, ölüm şekli ve buna bağlı muhtemel ölüm sebebi belirlemelerinde kullanılabilir nitelikte olduğunu göstermiştir. Bu çalışmadan elde edilen bulgular; adli antropolojik olgularda kurbanların hukuki süreçlerinin başlatılması veya devamı açısından, ölüm şekilleri ve buna bağlı muhtemel ölüm sebeplerinin belirlenmesi, kasitlı ve kasıtsız ölümlerin gün 1şığına çıkarılması, eğer varsa suçluların/sorumluların hak ettikleri cezaları almaları açısından ciddi derecede önem taşımaktadır.

$\mathrm{Bu}$ çalışma ayrıca, adli tıp ve adli antropoloji bilimlerinin birbirilerine olan katkılarına dikkat çekmek, gerekliliği ve önemi hakkında farkındalık yaratmak ve adli bilimler çalışmalarına yeni bir bakış açısı getirmek amacıyla da yapılmıştır. Burada ortaya çıkan disiplinler arası çalışma örneğinin Türkiye ve Kuzey Kıbrıs'taki adli bilimler çalışmaları için bir ön model oluşturması hedeflenmiştir. Ayrıca bu çalışmanın sonuçları, dünyadaki diğer örnekleri gibi $(5,7,10)$ adli antropologların adli tıp uzmanları ile birlikte çalışmalarının öneminin, tıbbi ve hukuki süreçteki başarı ve kazanımlar açısından küçümsenemeyecek boyutlarda olduğunu göstermiştir.

\section{Teșekkür}

$\mathrm{Bu}$ araştırmanın gerçekleştirilmesi için onay ve destek veren Kuzey Kıbrıs Türk Cumhuriyeti Sağlık Bakanlığı'na, Lefkoşa Dr. Burhan Nalbantoğlu Devlet Hastanesi Başhekimi Dr. Bülent Dizdarlı, Radyoloji Klinik Şefi Dr. Dilaver Akdur, Patoloji Uzmanı ve Başhekim Yardımcısı Dr. Sonuç Büyük'e, Yataklı Tedavi Kurumları Dairesi Müdürü Dr. Katoyan Kobat'a ve tüm çalışma boyunca yardımlarını esirgemeyen Dr. Burhan Nalbantoğlu Devlet Hastanesi Radyoloji Bölümü ve Morg Bölümü çalışanlarına teşekkür ederiz.

\section{Kaynaklar}

1. Aktaş EÖ, Kaya A. Yaralama Suçlarının Adli Tıbbi Değerlendirilmesinde Kullanılan Kılavuza Bakış. Adli Tıp Bülteni. 2017;22(1):45-53. DOI: https://doi.org/10.17986/ blm.2017127141

2. Gündoğmuş Ü, Balc1 Y, Çetin G. Türk Ceza Kanunu'nda Tanımlanan Yaralama Suçlarının Adli Tip Açısından Değerlendirilmesi, TC Adalet Bakanlığı, Adli Tip Kurumu, Haziran 2013 güncellenmiş son hali.

3. Güzel S, Balcı Y, Çetin G. Yeni Türk Ceza Kanunu'nda Tanımlanan Yaralanma Suçlarının Adli Tıp Açısından Değerlendirilmesi ve Adli Rapor Tanzimi İçin Rehber, Eylül 2005. 
4. Karbeyaz K, Gündüz T, Balcı Y. Yeni Türk Ceza Kanunu Çerçevesinde Kemik Kırıklarına Adli Tıbbi Yaklaşım, Ulus Travma Acil Cerrahi Dergisi 2010, 16(5): 453-458.

5. Berryman EH, Lanfear KA. Forensic Anthropologists in Medical Examiner's and Coroner's Offices: A History, A Companion to Forensic Anthropology, ed. By C. D. Dirkmaat, Wiley-Blackwell, 2012, Part VII: 534-548.

6. Byers SN. Introduction to Forensic Anthropology: Death, Trauma and the Skeleton, A text book, Pearson and AB, 2010, s. 274-354.

7. Dirkmaat CD. Developments in Human Skeletal Trauma Analysis, in: A Companion to Forensic Anthropology, Part VII, Ed. By Deniis C. Dirkmaat, Blackwell Publishing, 2012, s.337-339.

8. Dirkmaat CD. A Companion to Forensic Anthropology, Wiley, Blackwell, 2015, Part VII, p.534-549.

9. Donato , Luca A, Vecchiotti C, Cipolloni L. Study of Skeletal Remains: Solving a Homicide Case with Forensic Anthropology and Review of the Literature, J.Forensic Anthropol., 2016, 1: 105. DOI: https://doi.org/10.4172/ jfa. 1000105

10. Rainwater WC, Crowder C, Hartnett MK, Fridie SJ, Figura JB, Godbold J et al. Forensic Anthropology at the New York Office of Chief Medical Examiner, A Companion to Forensic Anthropology, ed. By C.D.Dirkmaat, WileyBlackwell, 2012, Part VII: 549-592.

11. Pinherio J. Introduction to Forensic Medicine and Pathology, Chapter 2, In: Forensic Anthropology and Medicine: Complementary Sciences From Recovery to Cause of Death, Ed.by S.Schmitt, E.Cunha and J.Pinherio, Humana Press Inc., Totowa, NJ., 2006, p.13-37.

12. Schmitt A, Cunha E, Pinheiro J. Forensic Anthropology and Medicine; Complementary Sciences from Recovery to Cause of Death, Humana Press, Totowa, New Jersey, 2006.

13. Stanojevich V. The role of Forensic Anthropologist in a Death Investigation, Univ. Of Ontario Inst. Of Technology, Canada, June 18, 2012. DOI: https://doi.org/10.4172/21577145.1000154

14. Burke P.M. Forensic Pathology of Fractures and Mechanisms of Injury, Postmortem CT Scanning, CRC Press LLC, 2012.

15. Campobasso CP, Dell'Erba AS, Belviso M., MD, Di Vella G. Craniofacial Identification by Comparison of Antemortem and Postmortem Radiographs Two Case Reports Dealing With Burnt Bodies, Am J Forensic Med Pathol, 2007, 28: 182-186. DOI: https://doi.org/10.1097/ PAF.0b013e31806195cb

16. Harris L.S. Postmortem Magnetic Resonance Images Of The Injured Brain: Effective Evidence In The Courtroom, Foren. Sci. Int. 50 (1991) 179-185.

17. HartBL, Dudley MH, Zumwalt RE. Postmortem Cranial MRI and Autopsy Correlation in Suspected Child Abuse, Am. J Forensic Med Pathol. 1996 Sep, 17 (3): 217-24.

18. Lathrop LS, Nolte BK. Utility of Postmortem X-ray Computed Tomography (CT) in Supplanting or Supplementing Medicolegal Autopsies, Final Technical
Report NIJ Award 2010-DN-BX-K205, accepted January 2016, s.1-97.

19. Nolte KB, Mlady G, Zumwalt RE, Cushnyr B, Paul ID, Wiest PW. Postmortem X-ray Computed Tomography (CT) and Forensic Autopsy: A Review of the Utility, the Challenges and the Future Implications, Academic Forensic Pathology, 2011, 1(1):40-51. DOI: https://doi.org/10.23907/2011.007

20. Ateşçelik M, Gürger M. Acil Servise Künt Travma ile Başvuran Hastaların İncelenmesi, 2013, Cilt 18, Sayı 2, 2013, Sayfa(lar) 103-108.

21. El-Menyar A, El-Hennawy H, Al-Thani H, Asim M, Abdelrahman $\mathrm{H}$, Zarour A et al. Traumatic injury among females: does gender matter?, J Trauma Manag. Outcomes. 2014, 8: 8. DOI: https://doi.org/10.1186/1752-2897-8-8

22. Gören S, Subaşı M, Tıraşcı Y, Kaza Z. Trafik Kazalarına Bağlı Ölümler, Türkiye Klinikleri Adli Tıp Dergisi, 2005, 2:9-13.

23. Leth PM, Ibsen M. Abbreviated Injury Scale Scoring in Traffic Fatalities: Comparison of Computerized Tomography and Autopsy, Journal of Trauma Injury, Infection, and Critical Care, June 2010, 68(6):1413-6. DOI: https://doi.org/10.1097/TA.0b013e3181b251b8.

24. Topcuoğlu MŞ, Kısacıkoğlu B, Salih K, Pekediz A, Yalınız $\mathrm{H}$, Bayram $\mathrm{H}$ et al. Alt Ekstremitenin İskelet ve Yumuşak Dokular ile Komplike Vasküler Yaralanmalarda Properatif Değerlendirme, UTD 1996, 2:180-4.

25. Yağmur Y, Uğur M, Kara İH, Güloğlu C, Aldemir M, Kiraz M. Acil Servise Başvuran Multitravmalı Olgularda Travma Skorları ile AT-III, Trombosit Sayıs1, APTT, PT ve Fbrinojen Düzeylerinin Değerlendirilmesi, T. Klin. J. Med. Sci., 2000, 20:123-31.

26. Veysi VT, Vassilios SN, Paliobeis C, Efstathopoulos N. Prevalence of chest trauma, associated injuries and mortality: a level I trauma centre experience, Int. Orthop., 2009 Oct, 33(5): 1425-1433. DOI: https://doi.org/10.1007/ s00264-009-0746-9.

27. Değirmenci B, Akar T, Demirel B. Ölümlü Trafik Kazalarının Adli Tıp Açısından Değerlendirilmesi, Gazi Medical Journal, 2015, Vol 26. No.4

28. Demirel, BC. Kafa ve Yüz Travmalarının Adli Tıp Açısından Önemi, T.C. Ege Üniversitesi Tıp Fakültesi Adli Tıp Ana Bilim Dalı, Bitirme Tezi, 2015, İzmir.

29. Bulger EM, Arneson MA, Mock CN, Jurkovich GJ. Rib Fractures in The Elderly, J Trauma-Injury Infec Crit Care. 2000, 48(6):1040-1046.

30. Lee RB, Bass SM, Morris JA, Jr MacKenzie EJ. Three or more rib fractures as an indicator for transfer to a Level I trauma center: a population-based study, J. Trauma-Injury Infect Crit Care.,1990, 30(6):689-694.

31. Sirmali M, Türüt H, Topçu S, Gülhan E, Yazici U, Kaya S et al. A Comprehensive Analysis of Traumatic Rib Fractures: Morbidity, mortality and management, European Journal of Cardio-Thoracic Surgery, 1 July 2003, 24 (1): 133-138.

32. Lau E, Ong K, Kurtz S, Schmier J, Edidin A. Mortality Following the Diagnosis of a Vertebral Compression 
Fracture in the Medicare Population, J Bone Joint Surg Am. 2008 Jul;90(7):1479-86. DOI: https://doi.org/10.2106/ JBJS.G.00675.

33. Makino Y, Yokota H, Nakatani E, Yajima D, Inokuchi G, Motomura A et al. Differences between postmortem CT and autopsy in death investigation of cervical spine injuries, Forensic Sci Int., 2017 Dec, 281:44-51. DOI: https://doi. org/10.1016/j.forsciint.2017.10.029.

34. Godoy JMP, Echeverria FR, Baitello LA, Espada PC, Morioka YR. Prevalence of Death Due to Pulmonary Embolism After Trauma, Lung India. 2010 Apr-Jun, 27(2): 72-74.DOI: https://doi.org/10.4103/0970-2113.63610

35. Alunni-Perret V, Muller-Bolla M, Laugier JP, Lupi-Pegurier L, Bertrand MF, Staccini $\mathrm{P}$ et al. Scanning Electron Microscopy Analysis of Experimental Bone Hacking Trauma, J. Forensic Sci., 2005, 50(4): 796-801.

36. Ambade VN, Godbole HV. Comparison of Wound Patterns in Homicide by Sharp and Blunt Force, Forensic Sci. Int.,2006, 156: 166-170. https://doi.org/10.1016/j. forsciint.2004.12.027

37. Bashir M, McWilliams RG, Desmond M, Kuduvalli M, Oo A, Field M. Blunt Aortic Injury Secondary to Fragmented Tenth Thoracic Vertebral Body, Ann. Thorac. Surg, 2013, (95): 2161-2164. DOI: https://doi.org/10.1016/j. athoracsur.2012.09.065.

38. Berryman HE, Symes SA. Recognizing Gunshot and Blunt Cranial Trauma Through Fracture Interpretation, Forensic Osteology, Ed. By K.J.Reichs (1998), s. 333-352.

39. Fachhini F, Rastelli E, Belcastro MG. Peri Mortem Cranial Injuries from a Medieval Grave in Saint Peter's Cathedral, Bologna, Italy, Int. J. Osteoarchaeol., 2008, 18: 421-430. https://doi.org/10.1002/oa.949

40. Gina O, Hart MA. Fracture Pattern Interpretation in the Skull: Differentiating Blunt Force From Ballistics Trauma
Using Concentric Fractures, Journal of Forensic Sciences, Volume:50, Issue:6, November 2005, s. 1276-1281.

41. Gozna ER. Biomechanics of Long Bone Injuries, In E.R. Gozna and I.J. Harrington (eds), Biomechanics of Musculoskeletal Injury Williams and Wilkins, Baltimore, MD., 1982, s. 1-24.

42. Harkess JW, Ramsey WC, Harkess JW. Principles of fractures and dislocations, In C.A. Rockwood, D.P., 1996.

43. Humphrey C, Kumaratilake J, Henneberg M. Variability of Characteristics of Cranial Projectile Trauma in Skeletal Material, Anthropol Anz., 2017 Dec 1,74(4):283-296. DOI: https://doi.org/10.1127/anthranz/2017/0774.

44. Gurdjian ES, Webster JE, Lissner HR. The Mechanism of Skull Fracture, Radiology, 1950, 54(3): 313 - 338. DOI: https://doi.org/10.1148/54.3.313

45. Kimmerle EH, Baraybar JP, Skeletal Trauma: Identification of Injuries Resulting From Human Rights Abuse and Armed Conflict, CRC Press Taylor \& Francis Group, USA 2008.

46. Lovell Nancy C. Trauma Analysis in Paleopathology, Yearbook Of Physical Anthropology, 1997, 40:139-170.

47. McNulty LS. An Analysis of Skeletal Trauma Patterning of Accidental and Intentional Injury, PhD diss, The University of Tennessee, Knoxville, 2016.

48. Passalacqua VN, Rainwater WC. Skeletal Trauma Analysis: Case Studies in Context, Wiley Blackwell, 2015.

49. Pechnikova M. Forensic Analysis of Bone Fractures Caused by Blunt Force Trauma, PhD diss., Masaryk University, Czech Republic, 2013

50. Cecchetto G, Fais P, Giraudo C, Boscolo-Berto R, Amagliani A, Miotto D et al. Micro-CT Features of Intermediate Gunshot Wounds Severely Damaged by Fire, Int. J. Legal Medicine, March 2013, Volume 127, Issue 2, pp 419-425. DOI: https://doi.org/10.1007/s00414-012-0775-6. 